Pages: $1-7$

\title{
PENGARUH KONSENTRASI AIR BAKU TERHADAP PERTUMBUHAN TANAMAN SELADA PADA BUDIDAYA HIDROPONIK
}

\author{
Anugerah Fitri Amalia ${ }^{1}$, Andi Dalapati ${ }^{1}$, Jonni Firdaus ${ }^{1}$, Pujo Haryono ${ }^{1}$, Elli Rachmawatie ${ }^{2}$ \\ ${ }^{1}$ Balai Pengkajian Teknologi Pertanian (BPTP) Sulawesi Tengah \\ ${ }^{2}$ Jurusan Biologi, Fakultas Sains dan Teknologi Terapan, Universitas Ahmad Dahlan \\ E-Mail: penulis. anugerahamalia808@gmail.com
}

Diterima : 11 September 2021

Disetujui : 21 September 2021

\begin{abstract}
Hydroponic cultivation is a method of cultivating plants using water without using soil. This planting technique depends on the concentration of raw water. The aim of the study was to determine the effect of the concentration of raw water on lettuce production. This research was conducted in This research was carried out from February to March 2021. Located in the courtyard of the Central Sulawesi Agricultural Technology Assessment Center (BPTP), Maku Village, PaluKulawi Poros Region. The research method used a non-factorial Completely Randomized Design (CRD), namely the use of two concentrations of raw water (soil raw water and distilled water) to dissolve AB Mix nutrients (factor A) with 2 treatment levels. Each treatment was repeated 5 times so that 10 replications were obtained. The concentration treatment of AB Mix nutrient solution used is: A1 = 392 ppm Soil Raw Water + 1200 ppm AB Mix solution and A2 = 31 ppm Distilled Raw Water +1200 ppm AB Mix solution. The data analysis method used is the Paired Sample T Test analysis or also commonly referred to as the two-sample difference test in pairs. Paired Sample T Test, which is a similar sample but carried out two different treatments with the help of SPSS 22.0 for windows. Based on the test results between Soil Raw Water and Distilled Raw Water, it is stated that there is a significant difference between the two, where the results of the paired sample t-test based on the significance value (Sig.) of plant height is known to be the Sig value. (2-tailed) is $0.000<0.05$ then $\mathrm{H} 0$ is rejected and $\mathrm{Ha}$ is accepted and $\mathrm{t}$ is 5.087. For the number of leaves, the Sig value is known. (2-tailed) is $0.000<0.05$ then $\mathrm{H} 0$ is rejected and Ha is accepted and $\mathrm{t}$ is 5.087. And for plant weight, the Sig value is known. (2-tailed) is 0.0100 .05 then H0 is accepted and Ha is rejected and t is 4.665. So it can be concluded that there is a difference between Soil Raw Water and Distilled Raw Water on the yield of lettuce growth.
\end{abstract}

Keywords: Raw Water, Hydroponics, Paired Sample T Test, Completely Randomized Design (CRD), Lettuce.

\begin{abstract}
ABSTRAK
Budidaya hidroponik merupakan metode dalam budidaya menanam dengan menggunakan air tanpa mengggunakan tanah. Teknik menanam ini bergantung dengan konsentrasi dari air baku.Tujuan Penelitian adalah untuk mengetahui pengaruh konsentrasi air baku terhadap hasil produksi tanaman selada. Penelitian ini dilakukan pada bulan Penelitian ini dilaksanakan pada bulan Februari hingga Maret 2021. Bertempat di dalam Halaman Kantor Balai Pengkajian Teknologi Pertanian (BPTP) Sulawesi Tengah, Desa Maku, Daerah Poros Palu-Kulawi. Metode penelitian mengunakan Rancangan Acak Lengkap (RAL) non faktorial yaitu penggunaan dua konsentrasi air baku (air baku tanah dan air destilasi) untuk melarutkan nutrisi $\mathrm{AB}$ Mix (faktor A) dengan 2 taraf perlakuan. Masing-masing perlakuan diulang sebanyak 5 kali sehingga didapat 10 ulangan. Adapun perlakuan konsentrasi larutan nutrisi AB Mix yang digunakan adalah : A1 = 392 ppm Air Baku Tanah + 1200 ppm larutan AB Mix dan A2 = 31 ppm Air Baku Destilasi + 1200 ppm larutan AB Mix. Metode analisis data yang digunakan adalah analisis Paired Sample T Test atau juga biasa disebut sebagai uji beda dua sampel berpasangan. Paired Sample T Test yaitu sampel yang serupa namun dilakukan dua perlakuan yang berbeda dengan berbantuan SPSS 22.0 for windows. Berdasarkan hasil uji antara Air Baku Tanah dan Air Baku Destilasi menyatakan bahwa terdapat perbedaan yang signifikan diantara keduanya, dimana hasil uji paired sample t-test berdasarkan nilai signifikansi (Sig.) tinggi tanaman diketahui nilai Sig. (2-tailed) adalah sebesar 0,000 < 0,05 maka H0 ditolak dan Ha diterima dan t sebesar 5,087. Untuk jumlah daun diketahui nilai Sig. (2-tailed) adalah sebesar 0,000 < 0,05 maka H0 ditolak dan Ha diterima dan t sebesar 5,087. Dan untuk berat tanaman diketahui nilai Sig. (2-tailed) adalah sebesar 0,010 >0,05 maka H0 diterima dan Ha ditolak dan t sebesar 4,665. Sehingga dapat disimpulkan bahwa ada perbedaan antara Air Baku Tanah dan Air Baku Destilasi terhadap hasil pertumbuhan selada..
\end{abstract}

Kata kunci: Air Baku, Hidroponik, Paired Sample T Test, Rancangan Acak Lengkap (RAL), Selada. 


\section{PENDAHULUAN}

Indonesia merupakan negara yang kaya akan sumber daya hayati, salah satu wilayahnya yaitu Sulawesi Tengah. Menurut BPS Sulawesi Tengah (2015) sektor pertanian merupakan penyumbang terbesar Produk Domestik Regional Bruto (PDRB) yaitu sebesar 48,79\%. Luas lahan pertanian di Sulawesi Tengah sebesar $29.687 \mathrm{Ha}$ (BPS, 2018). Akan tetapi, Sulawesi Tengah merupakan salah satu provinsi di Indonesia yang rawan bencana alam, khusus gempa bumi. Pada tanggal 10 Agustus 1968 terjadi gempa bermagnitudo 7,3 SR yang mengakibatkan gelombang tsunami besar di kawasan pantai Donggala (Newsletter, 1968), kemudian terulang pada tahun 2018 di wilayah Palu, Sigi, dan Donggala bermagnitudo 7,3 SR disertai liquifaksi dan tsunami. Menurut Pusgen (2018) wilayah Sulawesi Tengah berada pada posisi retakan (sesar). Bencana alam yang terjadi tahun 2018 menyebabkan terjadinya berbagai kerusakan,salah satunya sektor pertanian. Terdapat lahan pertanian yang sudah tidak dapat digunakan lagi, baik itu akibat terjadinya perubahan struktur tanah ataupun kerusakan jaringan untuk pengairan.

Selain topografi yang rawan terhadap bencana alam, Sulawesi Tengah pun termasuk wilayah stanting (kurangnya pmenuhan gizi keluarga). Tingkat konsumsi pangan sebagian penduduknya masih dibawah anjuran pemenuhan gizi, baik secara kualitas maupun kuantitas. Oleh karena itu salah satu upaya pemerintah saat ini dalam meningkatkan ketahanan pangan dan gizi masyarakat dengan cara mendukung ketahanan pangan, seperti lahan pekarangan. Ketahanan pangan merupakan kondisi terpenuhinya pangan bagi setiap rumah tangga yang tercermin dari tersedianya pangan yang cukup, baik jumlah maupun mutunya, aman, merata dan terjangkau.

Salah satu kegiatan pemanfaatan pekarangan yang mudah dan tidak memerlukan lahan yang luas yaitu budidaya hidroponik. Budidaya hidroponik merupakan cara bercocok tanam tanpa menggunakan media tanah melainkan dapat menggunakan air. Kelebihan dari budidaya hidroponik yaitu keberhasilan pertumbuhan tanaman dan berproduksi lebih terjamin, lebih praktis, pemakaian pupuk lebih hemat, tanaman dapat tumbuh dengan pesat dan tidak kotor, hasil produksi lebih kontinu, serta beberapa tanaman dapat dibudidayakan di luar musim (Lingga, 2005).

Sistem hidroponik dapat memberikan suatu lingkungan pertumbuhan yang lebih terkontrol. Dengan pengembangan teknologi, kombinasi sistem hidroponik dengan membran mampu mendayagunakan air, nutrisi, pestisida secara nyata lebih efisien (minimalis system) dibandingkan dengan kultur tanah (terutama untuk tanaman berumur pendek). Penggunaan sistem hidroponik tidak mengenal musim dan tidak memerlukan lahan yang luas dibandingkan dengan kultur tanah untuk menghasilkan satuan produktivitas yang sama (Karsono, Sudarmodjo \& Sutioso, 2002).

Nutrisi hidroponik sangat berpengaruh didalam budidaya hidroponik terhadap pertumbuhan tanaman. Kandungan air baku juga dapat mempengaruhi kandungan unsur makro dan mikro didalam larutan nutrisi. Jika konsentrasi air bakunya tinggi, kandungan nutrisi dapat mempengaruhi pertumbuhannya. Melalui sistem hidroponik ini di harapkan dapat ketahanan pangan dan gizi masyarakat. Namun konsentrasi air baku setiap wilayah berbeda-beda. Oleh karena itu perlu penelitian tentang pengaruh konsentrasi air baku terhadap pertumbuhan dan produksi dari tanaman selada dengan sistem hidroponik. Tujuan dari penelitian ini adalah untuk mengetahui pengaruh konsentrasi air baku terhadap hasil produksi tanaman selada.

\section{BAHAN DAN METODE}

\section{Lokasi dan Waktu Penelitian}

Penelitian ini dilaksanakan pada bulan Februari hingga Maret 2021. Bertempat di dalam Halaman Kantor Balai Pengkajian Teknologi Pertanian (BPTP) Sulawesi Tengah, Desa Maku, Daerah Poros Palu-Kulawi.

\section{Alat dan Bahan Penelitian}

Alat yang digunakan dalam penelitian ini adalah Instalasi hidroponik metode DFT (Deep Flow Technique), Net pot, Bak plastik, rock woll, Tray semai, handspayer, ember larutan nutrisi, total dissolved solids (TDS meter), thermometer, $\mathrm{pH}$ meter, electrical conductivity (EC) meter, timbangan digital, kamera dan alat tulis. Bahan yang digunakan pada penelitian nutrisi AB Mix, bibit selada, kertas label, air baku tanah (air sumur bor) dan air destilasi (air buangan AC).

\section{Metodologi Penelitian}

Penelitian ini menggunakan Rancangan Acak Lengkap (RAL) non faktorial yaitu penggunaan dua konsentrasi air baku (air baku tanah dan air destilasi) untuk melarutkan nutrisi AB Mix (faktor A) dengan 2 indikator perlakuan. Masing-masing perlakuan diulang sebanyak 5 kali sehingga didapat 10 
ulangan. Setiap unit percobaan terdiri dari 50 tanaman, 2 unit terdiri dari tanaman sampel sehingga jumlah total tanaman adalah 100 tanaman. Pengambilan data dilakukan sebanyak tiga kali sehari (pagi, siang, dan sore) bertujuan untuk mengetahui suhu larutan, $\mathrm{pH}$ larutan, nilai total dissolved solids (TDS meter) larutan, dan nilai electrical conductivity (EC) meter larutan. Adapun pengambilan data yang diperlukan dalam pengamatan yaitu tinggi tanaman, berat tanaman, jumlah daun, $\mathrm{pH}$ air baku, dan suhu larutan nutrisi. Pengamatan ini juga ditunjang dengan alat untuk mengukur parameter pengamatan, seperti: TDS meter (Total Dissolved Solids) merupakan alat ukur untuk mengukur total padatan atau partikel terlarut dalam air yang berfungsi mengukur konsentrasi larutan zat terlarut. Thermometer berfungsi mengukur suhu larutan air, dan $\mathrm{pH}$ meter berfungsi untuk mengukur tingkat keasaman dari suatu benda (umunya cairan atau tanah).

Pada pengamatan terdapat dua parameter perlakuan berdasarkan konsentrasi air baku ditambah standar konsentrasi larutan untuk jenis tanaman selada. Berikut parameter perlakuan konsentrasi larutan nutrisi $\mathrm{AB}$ Mix yang digunakan, yaitu

$\mathrm{A} 1=392$ ppm Air Baku Tanah +800 ppm larutan $\mathrm{AB}$ Mix

$\mathrm{A} 2=31 \mathrm{ppm}$ Air Baku Destilasi +800 ppm larutan $\mathrm{AB}$ Mix

Metode analisis data yang digunakan adalah analisis Paired Sample T Test atau juga biasa disebut sebagai uji beda dua sampel berpasangan. Paired Sample T Test yaitu sampel yang serupa namun dilakukan dua perlakuan yang berbeda dengan berbantuan SPSS 22.0 for windows.

\section{HASIL DAN PEMBAHASAN}

\section{Interaksi Air Baku Tanah dan Air Baku Destilasi terhadap Tinggi Tanaman Selada}

Berdasarkan hasil penelitian menunjukkan perbedaaan nilai tinggi tanaman pada setiap perlakuan. Hal ini disebabkan adanya perbedaan konsentrasi air baku yang diberikan pada setiap perlakuan. Berikut data ditampilkan pada tabel 1:

Tabel 1. Interaksi Air Baku Tanah dan Air Baku Destilasi terhadap Tinggi Tanaman Selada

\begin{tabular}{cccccccc}
\hline Indikator & $\begin{array}{c}\text { Rata-Rata } \\
\text { Tinggi }(\mathbf{c m})\end{array}$ & Mean & $\begin{array}{c}\text { Std. } \\
\text { Deviation }\end{array}$ & $\begin{array}{c}\text { Std. Error } \\
\text { Mean }\end{array}$ & Correlation & Sig. $\begin{array}{c}\text { Sig. (2- } \\
\text { tailed) }\end{array}$ \\
\hline Air Destilasi & 10,98 & 10,9750 & 6,64969 & 1,91960 & \multirow{2}{*}{, 998} &, 000 &, 000 \\
Air Tanah & 9,48 & 9,4833 & 5,72409 & 1,65240 & & & \\
\hline
\end{tabular}

Sumber : Data Sekunder Setelah Diolah, 2021

Berdasarkan hasil pengamatan (Tabel. 1) menunjukkan bahwa pertumbuhan tinggi optimal terdapat pada konsentrasi air baku destilasi dimana hasil yang diperoleh sebesar $10,97 \mathrm{~cm}$. Hal ini membuktikan bahwa pertumbuhan tinggi tanaman yang lebih baik menggunakan konsentrasi air baku sebesar 31 ppm. Dimana di ketahui bahwa air baku tanah memiliki kandungan zat kapur yang tinggi. Menurut Suryani (2015) menyatakan bahwa konsentrasi maksimum kualitas air sebesar diatas $200 \mathrm{ppm}$ memiliki kandungan elemen sulfat $\left(\mathrm{SO}_{4}\right)$.

Nilai mean atau rata-rata tinggi tanaman selada berdasarkan konsentrasi air baku destilasi sebesar sebesar 10,97 dan nilai konsentrasi air baku tanah sebesar 9,48 serta korelasi sebesar 0,998 dengan nilai probabilitas (Sig.) $0,000<0,05$. Korelasi sebesar 0,998 mengindikasikan korelasi interaksi air baku tanah dan air baku destilasi terhadap tinggi tanaman selada berhubungan secara nyata, karena nilai probabilitas $<0,05$. Pengambilan keputusan berdasarkan nilai probabilitas pengujian dua sisi (2-tailed), maka setiap sisi dibagi 2 sehingga $0,000 / 2=0,000$. Karena $0,000<0,025$, dengan demikian $\mathrm{H}_{0}$ ditolak dan dapat disimpulkan bahwa interaksi air baku tanah dan air baku destilasi berpengaruh terhadap tinggi tanaman selada. Menurut Herwibowo dan Budiana (2015) menyatakan air yang mengandung garam terlarut yang banyak dalam ukuran pemasokan air $200 \mathrm{ppm}$ atau lebih dapat menimbulkan masalah pada pertumbuhan tanaman.

\section{Interaksi Air Baku Tanah dan Air Baku Destilasi terhadap Berat Tanaman Selada}

Berdasarkan hasil penelitian menunjukkan perbedaaan nilai berat tanaman pada setiap perlakuan. Hal ini disebabkan adanya perbedaan konsentrasi air baku yang diberikan pada setiap perlakuan. Berikut data ditampilkan pada tabel 2 : 
Tabel 2. Interaksi Air Baku Tanah dan Air Baku Destilasi terhadap Berat Tanaman Selada

\begin{tabular}{cccccccc}
\hline Indikator & $\begin{array}{c}\text { Rata-Rata } \\
\text { Berat (gr) }\end{array}$ & Mean & $\begin{array}{c}\text { Std. } \\
\text { Deviation }\end{array}$ & $\begin{array}{c}\text { Std. Error } \\
\text { Mean }\end{array}$ & Correlation & Sig. & $\begin{array}{c}\text { Sig. (2- } \\
\text { tailed) }\end{array}$ \\
\hline Air Destilasi & 71,4 & 71,400 & 5,94138 & 2,65707 &,- 157 &, 800 &, 010 \\
Air Tanah & 54,8 & 54,800 & 4,43847 & 1,98494 & -157 \\
\hline
\end{tabular}

Sumber : Data Sekunder Setelah Diolah, 2021

Berdasarkan hasil pengamatan (Tabel. 2) menunjukkan bahwa berat optimal tanaman selada terdapat pada konsentrasi air baku destilasi dimana hasil yang diperoleh sebesar 71,40 gram. Hal ini membuktikan bahwa produksi tanaman selada (berat) lebih baik menggunakan konsentrasi air baku sebesar $31 \mathrm{ppm}$. Dimana di ketahui kualitas air baku mempengaruhi produksi tanaman. Menurut Suryani (2015) menyatakan bahwa kualitas air juga berpengaruh terhadap produksi tanaman yang dibudidayakan.

Nilai mean atau rata-rata berat tanaman selada berdasarkan konsentrasi air baku destilasi sebesar sebesar 71,40 dan nilai konsentrasi air baku tanah sebesar 54,80 serta korelasi sebesar ,157 dengan nilai probabilitas (Sig.) 0,800 >0,05. Korelasi sebesar -,157 mengindikasikan korelasi interaksi air baku tanah dan air baku destilasi terhadap berat tanaman selada tidak berpengaruh secara nyata, karena nilai probabilitas $>0,05$.
Pengambilan keputusan berdasarkan nilai probabilitas pengujian dua sisi (2-tailed), maka setiap sisi dibagi 2 sehingga $0,010 / 2=0,000$. Karena $0,005<0,025$, dengan demikian $\mathrm{H}_{0}$ ditolak dan dapat disimpulkan bahwa interaksi air baku tanah dan air baku destilasi berpengaruh terhadap berat tanaman selada. Menurut Rukmana (2007), faktor penting mempengaruhi produktivitas tanaman yaitu ketersedian unsur hara bagi tanaman.

\section{Interaksi Air Baku Tanah dan Air Baku Destilasi terhadap Jumlah Daun Tanaman Selada}

Berdasarkan hasil penelitian menunjukkan perbedaaan nilai jumlah daun tanaman pada setiap perlakuan. Hal ini disebabkan adanya perbedaan konsentrasi air baku yang diberikan pada setiap perlakuan. Berikut data ditampilkan pada tabel 3 :

Tabel 3. Interaksi Air Baku Tanah dan Air Baku Destilasi terhadap Jumlah Daun Tanaman Selada

\begin{tabular}{cccccccc}
\hline Indikator & $\begin{array}{c}\text { Rata-Rata } \\
\text { Jumlah Daun } \\
\text { (Helai) }\end{array}$ & Mean & $\begin{array}{c}\text { Std. } \\
\text { Deviation }\end{array}$ & $\begin{array}{c}\text { Std. Error } \\
\text { Mean }\end{array}$ & Correlation & Sig. & $\begin{array}{c}\text { Sig. (2- } \\
\text { tailed) }\end{array}$ \\
\hline Air Destilasi & 6,83 & 6,8333 & 2,58785 &, 74705 &, 989 &, 000 &, 002 \\
Air Tanah & 6,03 & 6,0000 & 1,95402 &, 56408 &, 989 \\
\hline
\end{tabular}

Sumber : Data Sekunder Setelah Diolah, 2021

Berdasarkan hasil pengamatan (Tabel. 3) menunjukkan bahwa jumlah daun optimal tanaman selada terdapat pada konsentrasi air baku destilasi dimana hasil yang diperoleh sebesar 6,83 atau 7 helai. Hal ini membuktikan bahwa jumlah daun tanaman selada lebih baik menggunakan konsentrasi air baku sebesar 31 ppm. Dimana di ketahui di antara faktor-faktor yang mempengaruhi sistem produksi tanaman secara hidroponik, larutan nutrisi menjadi salah satu faktor penentu yang paling penting dalam menentukan hasil dan kualitas tanaman, salah kualitas air baku (Nugraha, 2015). Menurut Mas'ud (2009) menyatakan pemberian nutrisi dengan berbagai konsentrasi dapat dijadikan metode untuk menemukan konsentrasi yang tepat terhadap pertumbuhan tanaman sesuai dengan macam jenisnya. Kesalahan pemberian salah satu unsur hara dapat menyebabkan kurang optimalnya pertumbuhan, jika pada tanaman kekurangan $\mathrm{N}$ maka akan terjadi pembatasan penyerapan unsur $\mathrm{P}$ dan dapat mengakibatkan ketergantungan unsur $\mathrm{N}$ pada proses pertumbuhan (Havlin et al, 2005). Menurut Wang et al. (2007) dan Homer (2008) bahwa kondisi pertumbuhan tanaman yang baik akibat tercukupinya hara $\mathrm{N}$ akan menyebabkan tanaman mampu menyerap $\mathrm{P}$ lebih efektif.

Nilai mean atau rata-rata jumlah daun tanaman selada berdasarkan konsentrasi air baku destilasi sebesar sebesar 6,83 dan nilai konsentrasi air baku tanah sebesar 6,03 serta korelasi sebesar 0,989 dengan nilai probabilitas (Sig.) $0,000<0,05$. Korelasi sebesar 0,989 mengindikasikan korelasi interaksi air baku tanah dan air baku destilasi terhadap jumlah daun selada berpengaruh secara nyata, karena nilai probabilitas $<0,05$. 
Pengambilan keputusan berdasarkan nilai probabilitas pengujian dua sisi (2-tailed), maka setiap sisi dibagi 2 sehingga $0,002 / 2=0,000$. Karena 0,001 $<0,025$, dengan demikian $\mathrm{H}_{0}$ ditolak dan dapat disimpulkan bahwa interaksi air baku tanah dan air baku destilasi berpengaruh terhadap jumlah daun tanaman selada. Jumlah daun yang berkembang secara signifikan dipengaruhi oleh hormon pertumbuhan daun, proses ini terjadi peningkatan pembelahan sel, dan mengarah pada perkembangan daun (Fahmi, 2010).

\section{Interaksi Air Baku Tanah dan Air Baku Destilasi terhadap Nilai pH Tanaman Selada}

Berdasarkan hasil penelitian menunjukkan perbedaaan nilai $\mathrm{pH}$ tanaman pada setiap perlakuan. Hal ini disebabkan adanya perbedaan konsentrasi air baku yang diberikan pada setiap perlakuan. Berikut data ditampilkan pada tabel 4 :

Tabel 4. Interaksi Air Baku Tanah dan Air Baku Destilasi terhadap Nilai pH Tanaman Selada

\begin{tabular}{cccccccc}
\hline Indikator & $\begin{array}{c}\text { Rata-Rata } \\
\text { Nilai pH }\end{array}$ & Mean & $\begin{array}{c}\text { Std. } \\
\text { Deviation }\end{array}$ & $\begin{array}{c}\text { Std. Error } \\
\text { Mean }\end{array}$ & Correlation & Sig. & $\begin{array}{c}\text { Sig. (2- } \\
\text { tailed) }\end{array}$ \\
\hline $\begin{array}{c}\text { Air Destilasi } \\
\text { Air Tanah }\end{array}$ & 7,51 & 7,5143 &, 22641 &, 03827 &, 597 &, 000 &, 031 \\
\hline
\end{tabular}

Sumber : Data Sekunder Setelah Diolah, 2021

Berdasarkan hasil pengamatan (Tabel. 4) menunjukkan bahwa nilai $\mathrm{pH}$ sesuai untuk hidroponik tanaman selada terdapat pada konsentrasi air baku tanah dimana hasil yang diperoleh dibawah dari 7,5. Hal ini membuktikan bahwa nilai $\mathrm{pH}$ tanaman selada tidak berpengaruh terhadap konsentrasi air baku. Menurut Syarieta et al., (2016) menyatakan nilai $\mathrm{pH}$ sangat berperan terhadap penyerapan nutrisi dalam bentuk ion. Dimana saat intensitas cahaya kuat, tanaman lebih menyukai nitrogen untuk diserap, maka tingkat keasaman menjadi menurun (angka $\mathrm{pH}$ naik). Untuk kondisi nilai $\mathrm{pH}$ diatas 7,5 ion besi, mangan, tembaga, seng, dan boron menjadi sulit untuk diserap oleh tanaman.

Nilai mean atau rata-rata nilai $\mathrm{pH}$ tanaman selada berdasarkan konsentrasi air baku destilasi sebesar sebesar 7,51 dan nilai konsentrasi air baku tanah sebesar 7,41 serta korelasi sebesar 0,597 dengan nilai probabilitas (Sig.) $0,000<0,05$. Korelasi sebesar 0,597 mengindikasikan korelasi interaksi air baku tanah dan air baku destilasi terhadap nilai $\mathrm{pH}$ tanaman selada berpengaruh secara nyata, karena nilai probabilitas $<0,05$. Pengambilan keputusan berdasarkan nilai probabilitas pengujian dua sisi (2-tailed), maka setiap sisi dibagi 2 sehingga $0,031 / 2=0,016$. Karena $0,016<0,025$, dengan demikian $\mathrm{H}_{0}$ ditolak dan dapat disimpulkan bahwa interaksi air baku tanah dan air baku destilasi berpengaruh terhadap nilai $\mathrm{pH}$ tanaman selada. Perubahan nilai $\mathrm{pH}$ yang ekstrim dapat mempengaruhi penyerapan nutrisi pada tanaman (Syarieta et al., 2016).

\section{Interaksi Air Baku Tanah dan Air Baku Destilasi terhadap Suhu Larutan Tanaman Selada}

Berdasarkan hasil penelitian menunjukkan perbedaaan nilai suhu larutan tanaman pada setiap perlakuan. Hal ini disebabkan adanya perbedaan konsentrasi air baku yang diberikan pada setiap perlakuan. Berikut data ditampilkan pada tabel 5 :

Tabel 5. Interaksi Air Baku Tanah dan Air Baku Destilasi terhadap Suhu Larutan Tanaman Selada

\begin{tabular}{cccccccc}
\hline Indikator & $\begin{array}{c}\text { Rata-Rata } \\
\text { Suhu }\left({ }^{\circ} \mathrm{C}\right)\end{array}$ & Mean & $\begin{array}{c}\text { Std. } \\
\text { Deviation }\end{array}$ & $\begin{array}{c}\text { Std. Error } \\
\text { Mean }\end{array}$ & Correlation & Sig. & $\begin{array}{c}\text { Sig. }(2- \\
\text { tailed) }\end{array}$ \\
Air Destilasi & 28,34 & 28,3429 & 1,41302 &, 23884 &, 484 &, 003 &, 025 \\
Air Tanah & 27,69 & 27,6857 & 1,79495 &, 30340 &, 484 \\
\hline
\end{tabular}

Sumber : Data Sekunder Setelah Diolah, 2021

Berdasarkan hasil pengamatan (Tabel. 5) menunjukkan bahwa suhu larutan yang normal pada tanaman selada terdapat konsentrasi air baku tanah dimana hasil yang diperoleh sebesar 27,69. Hal ini membuktikan bahwa nilai suhu larutan pada tanaman selada tidak berpengaruh terhadap 
konsentrasi air baku. Dimana di ketahui konsentrasi air baku tidak dapat mempengaruhi suhu larutan pada tanaman selada. Menurut Herwibowo dan Budiana (2015) menyatakan bahwa suhu larutan nutrisi idealnya berkisar $27^{\circ} \mathrm{C}$. Dimana pada tanaman tidak menyukai perubahan suhu yang cepat, terutama di zona perakaran.

Nilai mean atau rata-rata suhu larutan tanaman selada berdasarkan konsentrasi air baku destilasi sebesar sebesar $28,34{ }^{\circ} \mathrm{C}$ dan nilai konsentrasi air baku tanah sebesar $27,69{ }^{\circ} \mathrm{C}$, serta korelasi sebesar 0,484 dengan nilai probabilitas (Sig.) $0,003<0,05$. Korelasi sebesar 0,484 mengindikasikan korelasi interaksi air baku tanah dan air baku destilasi terhadap suhu larutan tanaman selada berpengaruh secara nyata, karena nilai probabilitas $<0,05$. Pengambilan keputusan berdasarkan nilai probabilitas pengujian dua sisi (2-tailed), maka setiap sisi dibagi 2 sehingga $0,025 / 2=0,016$. Karena $0,013<0,025$, dengan demikian $\mathrm{H}_{0}$ ditolak dan dapat disimpulkan bahwa interaksi air baku tanah dan air baku destilasi berpengaruh terhadap suhu larutan tanaman selada. Pada tanaman selada memiliki kisaran suhu ideal sebesar $20{ }^{\circ} \mathrm{C}-27{ }^{\circ} \mathrm{C}$. tanaman selada merupakan jenis tanaman yang tahan terhadap panas tapi tidak tahan terhadap suhu lembab, karena tanaman selada termasuk perishable (mudah rusak) (Syarieta et al., 2016).

\section{KESIMPULAN}

Berdasarkan hasil analisis data dan pembahasan tentang respon pertumbuhan tanaman selada terhadap konsentrasi air baku destilasi (31 ppm) dan air baku tanah (392 ppm), dapat disimpulkan bahwa konsentrasi air baku dapat mempengaruhi tinggi, berat, dan jumlah daun pada tanaman selada. Sedangkan pada konsentrasi air baku tidak dapat mempengaruhi pertumbuhan tanaman yaitu $\mathrm{pH}$ dan suhu larutan nutrisi pada tanaman selada. Kualitas air baku sangat mempengaruhi pertumbuhan dan jumlah produksi tanaman selada. Hal tersebut membuktikan konsentrasi atau kualitas air baku sangat berpengaruh terhadap budidaya hidroponik.

\section{UCAPAN TERIMA KASIH}

Ucapan terima kasih diberikan kepada Dr. Abdul Wahab, SP,. M.P selaku kepala Kepala Balai BPTP Sulawesi Tengah yang selalu memberikan suport dan masukan selama proses penulisan artikel ini, serta semua pihak yang telah ikut serta membantu dalam penulisan makalah ini.

\section{DAFTAR PUSTAKA}

Badan Pusat Statistik (BPS) Sulawesi Tengah. 2015. Statistik Produk Domestik Regional Bruto (PDRB) Sulawesi Tengah Badan Pusat Statistik.

Badan Pusat Statistik (BPS) Sulawesi Tengah. 2018. Statistik Luas Lahan Pertanian Sulawesi Tengah Badan Pusat Statistik.

Fahmi A, Syamsudin, Sri Nuryani H Utami, dan Bostang Radjagukguk. 2010. Pengaruh Interaksi Hara Nitrogen dan Fosfor terhadap Pertumbuhan Tanaman Jagung (Zea Mays L) pada Tanah Regosol dan Latosol. Berita Biologi 10 (3): 297304.

Havlin JL, JD Beaton, SL Tisdale and WL Nelson. 2005. Soil Fertility and Fertilizers. An Introduction to Nutrient Management. Seventh Edition. Pearson Education Inc. Upper Saddle River, New Jersey.

Herwibowo K, N.S. Budiana. 2015. Hidroponik Sayuran. Penebar Swadaya, Jakarta Timur.

Homer ER. 2008. The Effect of Nitrogen Application Timing on Plant Available Phosphorus. Thesis. Graduate School of The Ohio State University. USA

Karsono, S., Sudarmodjo, dan Y. Sutiyoso. 2002. Hidroponik Skala Rumah Tangga. Memanfaatkan Rumah dan Pekarangan. Depok: PT. Agromedia Pustaka

Lingga, P. 2005. Hidroponik Bercocok Tanam Tanpa Tanah. Jakarta: Penebar Swadaya.

Mas'ud, Hidayati. 2009. Sistem Hidroponik dengan Nutrisi dan Media Tanam Berbeda terhadap Pertumbuhan dan Hasil Selada. Program Studi Budidaya Pertanian. Fakultas Pertanian. Universitas Tadulako, Palu.

Newsletter. 1968. International Tsunami Information Hawai International Tsunami Information Center I (3)

Nugraha, Rizqi Utami. 2015. Sumber Sebagai Hara Pengganti AB mix pada Budidaya Sayuran Daun Secara Hidroponik. J. Hort Indonesia 6 (1): 11- 19. April 2015.

Pusat Gempa (Pusgen). 2018. Kajian Gempa Palu Provinsi Sulawesi Tengah Badan Penelitian dan Pengembangan Jakarta

Suryani, Reno. 2015. Hidroponik Budidaya Tanaman Tanpa Tanah. Arcitra, Yogyakarta.

Syarieta E, dkk. 2016. Hidroponik Praktis. PT Trubus Swadaya, Jakarta Pusat

Rukmana. 2007. Bertanam Petsai dan Sawi. Kanisius, Yogyakarta.

Wang YP, BZ Houlton and CB Field. 2007. A Model of Biogeochemical Cycles of Carbon, Nitrogen, and Phosphorus Including Symbiotic Nitrogen Fixation and Phosphatase Production. Global Biogeochemical Cycles 21, 1018-1029. 